\title{
Building intellectual bridges: from African studies and African American studies to Africana studies in the United States
}

\author{
Paul Tiyambe Zeleza \\ Bellarmine College of Liberal Arts, Loyola Marymount University \\ Los Angeles, California
}

\begin{abstract}
The study of Africa and its peoples in the United States has a complex history. It has involved the study of both an external and internal other, of social realities in Africa and the condition of people of African descent in the United States. This paper traces and examines the complex intellectual, institutional, and ideological histories and intersections of African studies and African American studies. It argues that the two fields were founded by African American scholar activists as part of a Pan-African project before their divergence in the historically white universities after World War II in the maelstrom of decolonization in Africa and civil rights struggles in the United States. However, from the late 1980 s and 1990 s, the two fields began to converge, a process captured in the development of what has been called Africana studies. The factors behind this are attributed to both demographic shifts in American society and the academy including increased African migrations in general and of African academics in particular fleeing structural adjustment programs that devastated African universities, as well as the emergence of new scholarly paradigms especially the field of diaspora studies. The paper concludes with an examination of the likely impact of the Obama era on Africana studies.
\end{abstract}

Key words: African studies, African American studies, African diaspora studies, Africana studies

The development of studies related to African peoples in the United States, variously produced in fields known as African studies and African American studies, have been molded and mediated, like other academic fields, by the unyielding demands and unpredictable dynamics of history. The origins, construction, and legitimation of disciplines, the production, dissemination and consumption of scholarly knowledges are conditioned by complex and sometimes contradictory, but always changing institutional, intellectual and ideological processes and practices that occur and intersect at local, national, and transnational levels. This is simply to point out that the growth of studies of African peoples has involved and their future will continue to entail interactive processes 
between internal and external factors within and outside the universities, academic and public constituencies, and national and global forces and transformations.

Studies of African peoples, phenomena and processes exhibit divergent organizational forms, academic tendencies, and social commitments. This can be explained by the different intersections of the local institutional context, the wider academic context, and the public context, or what the sociologist of professions, Andrew Abbott (1995), calls arenas. Academic fields, much like the professions in general, have to establish their boundaries of exclusive competence or special focus in order to legitimize, institutionalize, and reproduce themselves. This requires and is essential to securing resources, recognition, and respect from various constituencies that are so essential for survival. Thus, in assessing the current challenges and opportunities facing the studies of African peoples and their likely trajectories we need to better understand the historical and prevailing intellectual, institutional, and ideological contexts in which the field has developed.

At the risk of oversimplification one could argue African studies and African American studies, which when combined are commonly known as Africana studies in the United States, have had distinct and difficult, if overlapping, histories. Clearly, Africana studies represents a complex, incomplete, even contested amalgam of different traditions in the studies of African descended peoples within the United States, in Africa, and in other world regions.

The paper is divided into four parts. First, I will briefly trace the divergent and interwoven histories of African studies and African American studies before the Second World War. Second, I will examine their reconstitution during the era of decolonization in Africa and Civil Rights in the United States when the first academic programs in the two fields were established in U.S. universities. The third part focuses on the emergence of the Africana studies movement in the rg8os and I99os. I conclude with the rise of diaspora studies, the current institutional architecture of studies related to African peoples, and the likely impact of the Obama era on the field. All along, I will try to identify some of the key intellectual, institutional and ideological dynamics behind the changes in the constructions of the braided histories of African, African American, Africana and Diaspora studies.

Let me stress at the outset that the developments I will be discussing are not peculiar to Africana studies or the U.S., although they assume particular inflections for this field and in this country. The turns and twists, challenges and opportunities for Africana studies reflect the periodic restructuring of higher education, as well as reconfigurations of the social order, and the dynamics of political movements. Currently, we are witnessing changing patterns of global migrations, which are altering the demographic and diasporic formations in many countries including the United States. In this regard, it is worth pointing out the profound shifts in the world political economy including the rise of China and the other emerging economies, whose management, I suspect, will come to define the Obama era when today's polarized politics that undermines civil discourse and serious attention to the country's real challenges has been forgotten. 
In this brave new world, I contend, the newer fields such as Africana studies, women and gender studies, and environmental studies, to mention only a few, may embody the future better than the older disciplines incubated in the rgth century, in so far as they emerged out of epistemic and social struggles for interdisciplinary, intercultural, and international knowledges befitting the 2 ist century. Indeed, the former have played an important role in dismantling the hegemony of the older and often Eurocentric disciplines; but they, too, will need reorganization. In short, Africana studies will only succeed in escaping the stifling tentacles of the Eurocentric disciplines and embracing the full possibilities of interdisciplinary and engaged scholarship if it overcomes what Carole Boyce Davies (I999) calls the culturalist unicentricity and monologism of U.S. scholarship.

\section{The Inception of African Studies and African American Studies}

Ironically, African American scholar-activists in the Historically Black Colleges and Universities (HBCUs) founded both African studies and African American studies before the two fields diverged into institutional and intellectual solitudes from the r 950 s to the I9gos. This is not the story often told in the histories of African studies beloved in the Historically White Universities and Colleges (HWCUs) where African studies became dominant from the end of the Second World War. In such narratives, the birth of the field is attributed to the Cold War and its paternity accorded to Melville Herskovits. ${ }^{\text {T This un- }}$ derscores the simple fact that academic histories are revealing for what they say and leave out, what they seek to remember and to forget. They serve as weapons in the perennial struggles among academic disciplines for material resources and reputational capital; they serve to mark boundaries, stake positions, and confer authority.

It is not surprising that the key architects of both fields at the turn of the 2oth century were African American scholar-activists. For European American scholars in the burgeoning universities of Western Europe and North America, Africa and Africans were not serious subjects of study. ${ }^{2}$ Rather they were objects of derision, or at best primitive affirmations of the eternal superiority of Euroamerica. African American scholar-activists from Edward Blyden to Alexander Crummell and W.E.B. Dubois rejected such unapologetic Eurocentrisism. The writings of Dubois are emblematic of the intersections between the two fields. In his scholarly and popular publications he sought to reconstruct the histories and record the contemporary conditions of both African Americans and Africans, and offered searing indictments of racism in the United States and colonialism in Africa.

Clearly, for the founders of the two fields, the fate of African peoples on both sides of the Atlantic, indeed globally, were locked in suffocating webs of racial and colonial oppression, from which Pan-African solidarity and struggle held the keys to liberation.

This is the story told in Jane Guyer's (1996) monograph. For more nuanced histories of African studies that underscore the role of $\mathrm{HBCUs}$ and African American scholar activists in the foundation of the field, see Martin and West (1999), Zeleza (2003), and Robinson (2007).

2 For an old history of African studies in Western Europe, see Fyfe (1976). For the most recent account of the history of African studies in Europe, Asia, and the Americas see Zeleza (2007). 
They understood that Africa and its Diasporas suffered from mutually reinforcing European economic, existential, and epistemic violence. In their writings and politics, they sought to defend the integrity, experiences and contributions of Africans worldwide. They produced what has been called vindicationist scholarship, vindicating the humanity and historicity of African peoples, which was to mutate in subsequent generations into various nationalist and radical paradigms in African and African American studies.

This phase in the intertwined history of African studies and African American studies lasted until the Second World War. The struggle over the control of African and African American studies accelerated during the war as white scholars and institutions discovered American Negroes and African natives as potentially worthy subjects of scholarship. This discursive expression of wartime mobilization was played out in many arenas. Among them was the American Council of Learned Societies' Committee on Negro Studies founded in I94I (Harris I982). Herskovits exercised tight control over the work of the committee and deliberately sought to exclude the leading African American scholaractivists of the time including Ralph Bunche and Dubois, although he was not averse to using their services when he needed them. For him, scholarship had to be detached, so he loathed openly fighting racial segregation in the United States. This became increasingly untenable as the civil rights movement gathered momentum in the postwar era. At that point, Herskovits fully shifted his research interests to Africa. In 1948, he founded the Program of African Studies at Northwestern. Two years later, the ACLS Committee on Negro Studies collapsed.

Thus began the institutional, intellectual, and ideological split between African studies and African American studies. The study of Africa moved from the HBCUs to the HWCUs, from Howard to Northwestern, while intellectual authority shifted from activist scholars to professional academics, from Dubois to Herskovits. Studies of the African American experience focused on the history of the slave trade, often prefaced by broad outlines of the societies the enslaved Africans were taken from, the barbaric history of slavery, the struggles for abolition and the limits of emancipation, which was followed by a century of Jim Crow segregation. These scholars painstakingly unraveled the structural and social conditions of African American communities at the same time as they recorded the enormous contributions of African Americans to the development of the United States in all its economic, cultural, and political dimensions. Several of Dubois' books are emblematic of these broad thematic concerns ${ }^{3}$.

Among the topics that preoccupied many of the younger African American scholar activists, the growth of black urban communities and social classes featured high, most memorably in the works by Franklin Frazier ${ }^{4}$ and St. Clair Drake and Cayton ([1945] 1993). These scholars also examined, even celebrated, the development of African American culture including the expressive arts from music to literature. They vigorously debated the relative influence of African cultural survivals and American inventions in the

They include The Suppression of the African Slave Trade to the United States of America (1896), The Philadelphia Negro ([1899] 1998), and Black Reconstruction in America ([1935] 1998). 
growth of African American culture and identity. Thus, in this formative period, African American studies combined and often sought to counterbalance narratives of American racism with those of African American agency, struggle and achievement. These analytical preoccupations remained after the Second World War as the field became institutionalized. In contrast, white scholars who ventured into African American studies largely focused on the 'Negro problem'.

In the meantime, in African studies the epistemic canvas swung from African civilization to African modernization as Africa turned into a 'development problem'. Reinforcing this growing separation between African American studies and African studies was the national security imperative, the construction of area studies to bolster U.S, global power in its superpower rivalry with the Soviet Union. Locked in Cold War combat, which frequently turned into hot proxy wars in the newly invented Third World, winning hearts and minds as well as producing hegemonic knowledges of Africa, Asia, and Latin America became imperative. The area studies movement, in which African studies was now lodged, was centered in the HWUCs and bankrolled by the Federal government through its Title VI programs and the major foundations including Ford and Rockefeller that provided funding for area studies training and research'.

For the next few decades, African studies was infused with the twists and turns of American foreign policy, the projection of imperial power, in which knowledges of Euroamerica were universalized into disciplinary parables of the human condition and knowledges of Third World regions including Africa became particularized and even peculiar narratives of lack and becoming, lacking and becoming Europe. In this, African studies could not escape from the racialized paradigms, perspectives and practices of dominant American scholarship. The denigration of Africa and devaluation of Africans reflected and reproduced the epistemic racism that contaminated the work on minorities including African Americans.

Indeed, the exclusion of these populations from political and textual citizenship, from the American mainstream, necessitated the separation of their ancestral cultures and continents from disciplinary narratives. In short, given the centrality of race in American society and politics, the eternal solitudes between blacks and whites rooted in slavery and segregation, it meant that the privileges and pathologies of the wider American social and intellectual order were reflected and reproduced with a ferocious investment of patronage, passions, and pain in African studies in a manner that was unusual even among the area studies programs. More often than not, definitions and defamations of Africa were projections of attitudes to African Americans. The vocabulary used to depict the otherness and failed promises of Africa were often the same as that used for African Americans. This congruence of constructions and condemnations lay at the heart of the periodic contestations, often bitter, between African Americans, European Americans, and increasingly Africans in the study of Africa.

The inferiorization of Africa infected the area studies practitioners themselves as 
they came to be regarded by their colleagues in the American academy as parochial and less rigorous, intellectual deficiency syndromes they apparently hid behind interdisciplinary affectations. Anxious European American Africanists suffering from imagined complexes of African studies methodological and theoretical backwardness periodically abandoned the field and rediscovered the glories of U.S.-centric disciplines and debates, migrated to less maligned regions, or became regional comparativists and globalists ${ }^{6}$. Others sought to distance themselves further from African American studies, hoping to immunize themselves from the highly charged racial discourses evident in the field. Often forgotten in these academic hierarchies and maneuvers was the simple fact that disciplinary specialists focusing on the United States could function successfully without knowing anything about non-western societies; what was almost unheard of was an Africanist who only knew the society she studied or came from. In so far as intellectual rigor often comes from the demanding intersections of breadth and depth, it is far more exacting to be an area studies specialist than an ethnocentric disciplinary expert.

The professionalized and developmentalist thrust of African studies from the r950s reflected various trends in public policy and the academy. In the policy world, there was the territorialization of poverty as a Third World problem and the institutionalization of development practice (Escobar 1994). For its part, the commoditization and corporatization of academic culture forced and facilitated the divorce of academics from social movements, civic engagement, and public intellectualism (Jacoby 1987). Intellectual life became increasingly professionalized thanks to the explosive postwar expansion of university education and the growth of middle class comforts, consciousness, and conservatism, all of which spawned a social science research culture that valorized objectivity, detachment, and a mindless chase for theory. This expedited the separation of African studies from domestic African American constituencies and reinforced the use of deductive methods and models, in which Africa was reduced to a testing site for theories manufactured with faddish regularity in the American academy.

\section{The Era of Decolonization in Africa and Civil Rights in the United States}

The separation between African studies and African American studies entered a particularly complicated period from the 1960 s following African independence and the explosion in higher education on the continent and the nationalist project to decolonize education and culture ${ }^{7}$. In the meantime, the United States was convulsed by civil rights struggles, which inspired other movements including the anti-war and feminist movements. All these movements challenged hierarchies and hegemonies of power in American society and institutions including the universities ${ }^{8}$.

For a loud defense of the disciplinary relevance of African studies see Bates, et al. (1993)

7 These developments are explored briefly by Zeleza (2009) and at greater length in Zeleza and Olukoshi (2004a, 2004b).

8 The contexts and causalities between civil rights and the emergence of Black/African American studies are explored at length by Banks (1996), Aldridge and Young (2000), Gordon and Gordon (2006), and Rojas (2007). Also invaluable are the anthologies on Black studies (Bobo, Hudley, and Michel 2004) and Africana studies Barrett and Carey 2003; Azevedo 1998). 
There were intense reverberations between decolonization in Africa and civil rights in the U.S., which had epistemological and institutional consequences. Both independence and decolonization brought more African and African American students and faculty to predominantly white American universities. Independence brought more Africans to the U.S. seeking education to develop their postcolonial nations, while the civil rights movements opened doors to African Americans to white-dominated institutions and for migrants from Third World regions. The racism they encountered on these campuses and the exclusion of their societies, cultures and histories from the curriculum and disciplinary canons inflamed their nationalist passions and rekindled their Pan-African imaginations. Militant African American students who waged vocal protests for curricular relevancy, reform of higher education, social justice, community engagement, and inclusive democracy of course took the lead. Other minority students and liberal white students often supported them, especially in the early days.

The African American studies movement was both an ally and a foe of African studies. Many a reluctant university administration was forced to develop African studies programs in direct response to the institutional, intellectual, and ideological challenges posed by militant African American students, who were inspired by the Black consciousness, Black arts, and Civil Rights movements more generally, whose demands for courses on the Black experience soon turned into calls for Black studies departments, centers, institutes, or programs that should both be independent and involved in community service.

By challenging Eurocentric paradigms and the rigid barriers between academic disciplines, the African American studies movement helped legitimize the study of non-Western cultures and multidisciplinary and interdisciplinary studies. In short, as Manning Marable (I995) has reminded us, the African American studies movement was an integral part of the multiculturalism struggle that facilitated the entry of African studies programs and other minority and women studies programs into the academy. But by pointing to the configuration of European American power and domination in the American academy, even in African studies, and emphasizing the collective black experience, it challenged African studies in which the study of Africa and the African America and the African diaspora more generally were strictly separated.

\section{The Struggle for Black Studies}

In I968 and 1969, two pivotal events took place that poignantly captured the dawn of the new era in African American studies and African studies. The first was the student protest in I968 at San Francisco State University, which resulted in the established of the first Black Studies program in the country. Within three years, more than five hundred programs had been established. Both African American studies and African studies found themselves competing for resources and recognition at the HWCUs. By and large, the HBCUs hardly developed programs, as distinct from individual course offerings, in either field (Challenor 2002; Mann 2010).

The proponents of radical Black studies or what later came to be known as African American studies were soon stymied. The field was compromised by the integrationist impulses of 
white philanthropists, principally the Ford Foundation, who bankrolled the new programs and helped assuage the fears of white administrators thus paving way for the institutionalization of Black studies. This story has been told in fascinating detail by Noliwe Rooks (2006) in her book, White Money, Black Power. The Ford Foundation supported the establishment of African American studies primarily to promote racial integration and institutional diversity, that is, the diversification of students, faculty, and curricular.

This rhetoric appealed both to university administrators, many of whom introduced Black studies programs without student protests on their own campuses, and many Civil Rights icons that disapproved of the separatist ideology of Black Power, and older Black faculty who were not convinced of the intellectual merits of Black Studies. Between I 668 and 1972, the Ford Foundation made grants worth \$1o million to two-dozen Black Studies programs. Funding was restricted to those that sought to promote the Foundation's vision and set themselves up as 'a clearinghouse through which Black faculty, Black texts, and Black students could be funneled to traditionally white disciplines such as history, English, and sociology' (Rooks 2006: I2I).

The Institutionalization of African Studies

Also increasingly frustrated were the dreams of creating decolonized African studies, let alone Africana studies that encompassed both sides of the Atlantic. African studies suffered from the imperialist injunctions of the area studies model sanctioned by the state. In 1969 , a confrontation took place at the Annual Meeting of the African Studies Association in Montreal, where a group of African and African American scholars and activists challenged the Eurocentrisism of African studies and the control of African studies by white scholars. They called for more Black members and leadership, as well as the inclusion of Pan-Africanist perspectives, and political commitment to struggles for emancipation in Africa and in the U. S. from what they termed imperialist and racist oppression, exploitation, and marginalization.

The role of the U.S. Department of Education Title VI program in shaping area studies in the American academy is well known (Hawkins et al. r998; O'meara, et al. 2001; O'Connell and Norwood 2007; Wiley and Glew 2010). First passed under the National Defense Education Act of 1958 , the program clearly sought to bind the study of Africa, Asia, Latin America and the Soviet bloc to national security needs. Over the next three decades in subsequent reauthorizations to fund National Resource Centers and Foreign Language and Areas Studies fellowships, both the appropriations and mandates of Title VI expanded to include the promotion of American business competitiveness and other pressing national interests. As the Cold War wound down following détente and the collapse of the Soviet Union, Title VI funding declined despite the growth of area studies programs. Adjusted for inflation, it fell by 17 percent from $\$ 64.2$ million in 1967 to $\$ 53.3$ million in 1995 , while funding for Fulbright-Hays programs fell by 56 percent from $\$ 13.8$ to $\$ 5.8$ during the same period. Following $9 / \mathrm{II}$, the national security imperative returned with a vengeance and area studies funding skyrocketed. 


\section{The Solitudes of African American and African Studies}

By the 1970s, then, there were various competing paradigms and projects in African studies and African American studies. The funding formulas and ideological proclivities of the state and foundations reinforced the divisions. The Title VI program only awarded grants to 'foreign' area studies programs that were administratively and academically separate from 'domestic' ethnic studies programs. This not only sustained the separation between the two fields, it also presented an important structural barrier to the departmentalization of area studies. In cases where combined departments of African and African American studies were set up, independent African studies' centers were created to access Title VI funds. In the meantime, higher education funding for African Americans from the philanthropic organization including the Ford Foundation was almost exclusively confined to those pursuing Black Studies. In this way, the institutional divide became loudly racial: African studies programs were dominated by European Americans while African American studies programs became a preserve of African Americans.

\section{The Emergence of Africana Studies in the U.S. Academy}

By the early i 980 , about 600 institutions of higher education had established programs in Black studies, African American studies, Afro-American studies, or Africana studies. The proliferation of the nomenclature was itself an indication of the internal theoretical and methodological divisions in the field. According to various estimates, the number dropped to between 200 and 400 in the early I990s, thanks to internal dissensions, overwork, dwindling administrative support, partly because of the growing backlash against affirmative action, and growing competition for resources by other ethnic studies and thematic studies programs. Programs and faculty in African American studies were generally held in low esteem, as intellectually weak, an indictment they still suffer from. At best, they were valued for helping to advance the token diversification of Black faculty and curricula on campuses; at worst, they were tolerated as cheap concessions to affirmative action and political correctness.

The struggle for institutional stability and respectability took various forms as evident with the African American Studies programs at Temple and Harvard universities. The trajectory of the two programs also captures, quite starkly, the increasingly divergent institutional, intellectual, and ideological paths within African American Studies. In a fascinating comparative study, Mario Small (1999) notes that both programs, which had attained departmental status, were in the doldrums before the appointment of two remarkable chairs, Molefi Asante at Temple and Henry Louis Gates at Harvard in the mid-I980s and in the early I990s, respectively. Asante turned the field into an autonomous discipline, Africology, focused on Afrocentric agency and epistemology, and committed to engaged scholarship ${ }^{9}$. In contrast, Gates maintained African American Studies as an interdisciplinary field, open to multiple disciplinary 
methodologies, and unapologetically committed to scholarship and secondarily policy-centered work ${ }^{10}$.

The differences between the two programs reflected the different intellectual ambitions and ideological inclinations of the two men. But beyond personal inclinations and quirks, the different strategies they adopted to gain organizational stability and legitimacy reflected their respective institutional contexts, and academic and public constituencies. Temple had a much larger African American student body than Harvard. Moreover, Small argues, the Black community in Philadelphia was bigger, more important for Temple and more supportive of African American Studies at the university than was the case for Harvard in Cambridge. This explains the efforts by Asante's department to synergize activism and scholarship, compared to the more exclusive academic fixations of Gates' department.

In the wider academic arena, Asante appealed to a growing network of scholars who were committed to the development of the field as a distinctive discipline, vehemently opposed to Eurocentric perspectives, attracted to multiple epistemic voices, and enamored by Black Nationalism. His department established a number of journals that helped expand a distinctive space for Afrocentric knowledge production, circulation, and consumption. For his part, Gates focused his considerable entrepreneurial energies on building a 'dream team' of scholars who were already highly accomplished in their disciplines, and who enjoyed respect among the networks of prominent intellectuals. For such scholars joint appointments made sense and they were readily welcomed in their respective disciplinary departments that could simultaneously burnish their academic and diversity credentials. Instead of establishing a series of independent journals, prominence was given to data-collecting projects for analytical use by the existing disciplines. While rejecting social activism, Gates and his colleagues happily embraced the celebrity version of public intellectualism.

In the meantime, African studies programs were also undergoing their own shifts and contestations. The growing migrations of Africans to the United States, thanks to the depredations of structural adjustment programs and postcolonial authoritarianisms, which devastated African universities, brought a new mix in the perennial racial, intellectual, and ideological schisms of African studies. Their entry into U.S. universities offered African studies both an opportunity and a challenge. As migrants from predominantly Black societies, African migrant intellectuals were not always sensitive to the racial dynamics and demands of American society and the academy; some even internalized the dominant's society's negative stereotypes of African Americans, which often made them accomplices with European Americans in America's eternal racial war, for which they were sometimes rewarded with preferential hiring and promotion over African Americans ${ }^{11}$. By hiring a few

For the ups and downs of Gates's department, see The Journal of Blacks in Higher Education (2004) and for commentaries on Gates' Africanist work, see and Mbabuike (2000) and Zeleza (2003).

The question of Black faculty marginalization at predominantly white institutions continues to be a hotly debated issue. When I was invited to present an original version of this paper at Texas $A \& M, I$ was asked to do a workshop for Black faculty on the challenges minority faculty especially face in their career and epistemic negotiations in their disciplines and departments. I sent the workshop participants in advance the following reading materials: a special issue of the Journal of Black Studies (2003); Tillman (2001); Thomas and Hollenshead (2001); Stanley (2006, 2007); and Mathew and Grunwald (2006). It was vigorous, if at times, painful conversation. 
continental Africans, African studies programs gained credibility and universities shored up their affirmative action credentials.

The Africans, however, were not always so easily placated; their blackness assumed greater salience the longer they stayed in the U.S. especially as they and their families were forced to negotiate the country's treacherous racial quagmire and their children became African Americans or American Africans, as Ali Mazrui (1996) calls them. The gravitation towards African American grievances reinforced the Africans' own long-standing grumblings against the marginality of African voices in African studies. Hence, as have extensively documented elsewhere ${ }^{12}$, the growing trail of complaints by African scholars about the relevance and reliability, accountability and authority, biases and boundaries, concepts and constructions, definitions and distortions, integrity and imperatives, ideological attachments and intellectual agendas of the white dominated African studies enterprise.

Thus, by the r 990 os the divide between African studies and African American studies and within each field was institutional, intellectual, and ideological. Housed in separate, sometimes antagonistic units that often ignored each other; they examined the U.S. and Africa from distinctly different angles. The Africa of African studies was the sub-Saharan contraption examined through the gaze of modernization and development; the Africa of Afrocentric studies was continental and diasporic, focusing on the ancient past and transnational connections among African peoples. Similarly, African studies ignored African America, while many African American Studies programs ignored Africa. The gulf between development and diaspora, Africa and the diaspora, became deep and unproductive. The institutional divide was also racialized as white scholars dominated African studies programs and African American studies became largely confined to black scholars. African scholars often found themselves straddling between the two solitudes.

But this institutional architecture and intellectual division of labor was already creaking at the seams. Increasingly, joint programs of African and African American Studies started emerging on many campuses. Some were new, while others resulted from consolidation or expansion of previously separate programs. Formal mergers were difficult at universities hosting large Title VI funded African studies programs, although collaborations between these programs and African American studies programs began to increase if only to assuage growing student demands. But tensions often lurked behind the surface in the newly minted Africana studies programs. There were often four sets of tensions, which manifested themselves principally over faculty searches, course scheduling, and extra-curricular programming. The first was between African Americans and Africans; the second between men and women; the third between social scientists and humanists; and the fourth between those who prized scholarship and those who valorized activism ${ }^{13}$. It was a perfect site for crabs-in-a-bowl 
syndrome. It was not unusual for some black scholars not affiliated with the Africana studies departments to avoid their potentially toxic atmosphere and low reputation.

Nevertheless, the trend towards Africana studies was unmistakable. It was strengthened by the growing popularity of the diaspora paradigm, which led to the internationalization of African American studies beyond the U.S. to incorporate other African diasporas in he Americas and the trans-Atlanticization of African studies, the reconnection of studies of Africans on the continent and in the diaspora. This development can be accounted for by several factors. The first factor is demographic, the migration of unprecedented numbers of African academics to American universities ${ }^{14}$. This is tied to the overall increased migrations from Africa and other regions with large African diaspora populations such as the Caribbean and South America. The offspring of these migrants, or the new diaspora, are increasingly going to universities. Their cultural worlds, and intellectual quests, straddle Africa and the United States, interest in African studies and African American studies. To be sure, the majority of Black students whether from the historic or new diasporas do not major or even minor in these fields. But the point I want to make is that the combined growth of faculty and students from recent African migrant populations is shifting the terrain of Black identity on American campuses and the configuration of Black Studies.

This has become a source of censure, celebration, and concern among the advocates and antagonists of separate programs of African and African American Studies. For those who are opposed to the emergence of Africana studies from the African American side, their anxieties are partly fueled by apprehensions about affirmative action, the changing demographic profile of the United States including the apparent dissolution of blackness into hyphenated national and multiracial identities. This trepidation is expressed with considerable rage by Cecil Brown (2007) in his book Dude, Where's My Black Studies Department? in which he laments the disappearance of African American students and faculty from the University of California campuses and the takeover of Black Studies departments by racially timid and pliant overseers from the Caribbean and Africa who take refuge in diaspora studies. Such anguish has found its way to the mainstream media including the New York Times, which had an attention grabbing front page story a few years ago by Rimer and Arenson (2004): "Top Colleges Take More Blacks, But Which Ones?" The story, and others like it, noted the rapid increase in the numbers of first and second-generation students of African and Caribbean descent in elite colleges among Black students ${ }^{15}$.

This development is also quite disconcerting to those Africanists who relished unchallenged racial authority over the study of Africa; they prefer their beloved and distant Africa safely sealed from American academic racial politics. This is evident in two influential studies published as the Africana studies movement was emerging, in which idly. See some of the following, (Arthur 2000, 2009, 2010; Zeleza 2004, 2005, 2008; Okpewho and Nzegwu 2009)

I5 See a similar story in The San Francisco Gazette (Johnson 2005), and the reports by Eissa (2005) and Bennett and Lutz (2009). 
African studies is strictly confined to the study of continental Africa and separated from the study of the pan-African world (Bates et al. 1993; Guyer 1996). Africana studies reconnects Africa to the United States and brings African Americans back to African studies from where they were largely banished with the ascendancy of developmentalist scholarship in African studies and the establishment of African American Studies programs. Many Africanists see Africana studies as a racialized black space that threatens their fragile academic respectability derived from the fact that the interdisciplinarity of their African studies remained largely administrative not disciplinary. For many of them, Africana studies smacks of Afrocentricity, which they tend to disparage.

\section{The Rise of Diaspora Studies}

Increased migrations and formations of new African diasporas in the United States would not, by themselves, have led to the development of diaspora studies, which cemented Africana studies as the global study of African peoples. This development was tied in complex ways to other developments within and outside the academy. The intellectual dynamics included the rise of cultural studies, postcolonial studies, and globalization studies, which collectively recast the questions of culture, identity, and transnationalism in many humanities and social science fields including African studies and African American studies ${ }^{16}$.

Previously African studies had been dominated by developmentalist and structuralist perspectives, often superimposed on age-old Eurocentric notions of eternal African marginality, the strange fiction that the continent was irredeemably irrelevant and splendidly isolated from the rest of the world. Part of the appeal of the diaspora paradigm is that it promised to reconnect Africa to its peoples dispersed around the world and globalized Africa, repositioned the continent in world history.

Accompanying these intellectual imperatives were institutional dynamics, the establishment of centers, institutes, or programs of global, transnational, or cultural studies in which diaspora studies became the favored progeny. Alongside this was the emergence of journals, book series, and research funding on the subject. As with any field of scholarship, once you build the institutional architecture research and publications tend to follow, discourses and debates are manufactured, careers made and unmade. Since 2006, as I conducted my project on the global history of African diasporas that took me to sixteen countries (four each in continental South and North America, the Caribbean, Europe and Asia), I have watched the literature on African diasporas literally explode as scores of books and hundreds of articles are published each year. Trying to keep up with the literature has become increasingly impossible for any one individual.

The intellectual and institutional dynamics promoting diaspora studies have been facilitated and reinforced by ideological imperatives, the investment by states and various publics in diaspora communities, the popular discourses by and on diaspora populations, perspectives, problems, and possibilities. The discovery by African states and

I6 For succinct analysis on the growth and challenges of African diaspora studies, see Zeleza (20ro); for more detailed studies see Okpewho and Nzegwu (2009) and Olaniyan and Sweet (2010). 
development agencies of the new African diasporas as a developmental asset, as the continent's major donor - responsible for between $\$ 50$ and \$150 billion in remittance flows according to various estimates- is complimented by a growing consciousness on the part of the diasporas themselves and their capacity to act as powerful transnational forces.

This is best encapsulated in the designation of the diaspora by the African Union as Africa's sixth region although the implications of this are yet to be fully spelled out. In the meantime, many diaspora communities themselves have become more vocal in their self-representation, in their demands for difference and inclusion. On the one hand, this reflects the glocalization of pan-ethnic identities and racial formations, both old and new, and on the other the growth of bureaucratic multiculturalism. The role of international forums cannot be discounted. In this context, one can mention the mobilizational effects of the 200I UN World Conference against Racism for African diasporas from Brazil to India.

The flow of intellectual and ideological currents from and into the United States, which shook the barricades of institutional separatism between African Studies and African American Studies, was made possible by the very technologies and economies of globalization. The academy, in short, could not remain splendidly isolated from the growing intensity of global interconnectedness and competitiveness. The enhanced flows of capital and commodities extended to culture; the globalization of information and images included ideas; the transnationalization of people and politics encompassed paradigms as well.

This is to argue the development of Africana studies was part of a much broader movement. As I have written at length elsewhere, internationalization constitutes one of the key challenges and opportunities facing universities. It is driven internally by the growing complexity of knowledge and externally by the increasing commercialization of knowledge. It is quite evident that universities are becoming more interconnected internationally for both epistemic and economic reasons, the first because universities have always been, or aspire to be, universalist and universalizing institutions, an imperative reinforced by growing global reflexivity and the explosion of knowledge that makes transnational collaborations more important than ever; and the second because trade in educational services is expanding rapidly and even becoming subject to global trade rules and negotiations.

In a sense, the new intellectual moment in Africana studies rekindled by diaspora studies represents a road back to the future, to the African, diasporic, and global concerns and commitments of Du Bois, Dike, Diop, and Davidson, away from the prescriptive developmentralisms that dominated African studies and the domestic preoccupations that characterized African American studies in the late 1960 s and I970s. It marked a potential movement from the reformist and nationalist politics of conformity and careerism to the politics of Pan-African enlightenment, empowerment, engagement, and emancipation, of radically imagining a different future (Christian 2004; Gomez 2004; Griffin 2004; Hanchard 2004). Du Bois, as Reiland Rabaka (2006: 745) reminds us, was an insurgent, interdisciplinary intellectual, who addressed the challenges and crises of his times, espe- 
cially the political economies of racism, imperialism and liberation using critical social theory constructed out of transcultural, transnational, trans-ethnic, trans-gender, and trans-disciplinary approaches inspired by his enduring opposition to the interlocking systems of oppression and dedication to "human liberation, democratic political action, and social transformation."

Clearly, the emergence of new African diasporas and disapora studies challenges the conceptual registers of both African studies and African American studies and bring the two fields closer together. As Africa realizes it cannot ignore its new diasporas, in the diaspora communities and identities are being reconfigured as they become more pluralized. All this forces us to move beyond conventional African and U.S. categories of identity. As Beverly Guy-Sheftall (1998: 20) puts it with reference to the gendering of the field of women and African diaspora studies: "Racial categories familiar within this country are somewhat useless in a consideration of what we would call raciall ethnic women outside it." A fully transnational and transcultural paradigm of African diaspora studies, argues Davies (I999: I06), has to "speak to the variety of movements ushered in by migrations and the consistent reproduction of different modes of being in the world. Rather than a giant, monolithic, traditional African culture, then, we can assert multiple, transcultural presences within and outside Africa."

\section{The Institutional Architecture of African, African American, Africana and Diaspora Studies}

As a result of all these developments, Africana studies exhibits considerable diversity in the U.S. academy, which can be distinguished in terms of their institutional organization, location, and activities. In the first instance, some are organized as centers and others as departments. As for location, some are placed in colleges of liberal arts and sciences (or arts and letters), and others in schools of international studies or affairs. In terms of activities, the main difference is that some offer full degrees and others minors, concentrations, or certificates. A brief survey of shows institutions that have a history of receiving Title VI funding tend to have separate African studies centers and African American studies programs or departments. This is true at the flagship campuses of the universities of California, Illinois, Indiana, Florida, Kansas, Michigan, Michigan State, North Carolina, Ohio, Rutgers, and Wisconsin, as well at such leading private universities as Boston, Cornell, Harvard, Northwestern, Pennsylvania, Princeton, and Yale.

At some of these universities departments of African and African American or Africana studies have also been established alongside African studies programs. This is the case, for example, at the University of North Carolina-Chapel Hill, Harvard, Rutgers, University of Michigan, and University of Pennsylvania. In universities where separate African studies and African studies were not established before the rise of the Africana studies movement, stand-alone Africana studies departments have been created. This tends to be the case at the smaller or poorer universities among the lower-tier public and private universities and the HBCUs. There are notable exceptions such as Bard 
College, Brown University, Binghamton University, University of South Florida, and University of Wisconsin-Milwaukee where neither history nor resources are the decisive factors.

In a few cases, African studies centers not only exist alongside African American studies programs, but also with departments of African languages and literatures as is the case at the universities of Florida and Wisconsin. At several universities programs or departments of African and African diaspora studies have been created. Examples include Calvin College, Florida International University, Kennesaw State University, Tulane University and the University of Maryland. It is reasonable to expect that as the financial situation of many universities continues to deteriorate either because of declining public subventions or pressures on tuition rises and growth of endowments due to the Great Recession and its lingering effects, smaller academic programs are being eliminated or compelled to consolidate. Consolidation will help the growth of Africana studies programs and departments at the expense of separate African and African American studies programs.

Among the current 12 Title VI centers eight are located in colleges of arts and sciences (Boston, Harvard, Indiana, Florida, Kansas, North Carolina-Chapel Hill, Pennsylvania, Wisconsin), and four in schools of international studies (Michigan State, Ohio, Berkeley, and Yale). A similar pattern is evident for many of the institutions without Title VI African studies programs. The case of Michigan State is quite intriguing in that while African studies is in international studies, the department of African and African American studies is in the college of arts and letters. This is not the space to assess the merits or demerits of the different models of institutional location, except to note that it reflects the predominance of social science and humanities disciplines in area studies programs. This can limit the campus-wide appeal of area studies programs especially for faculty and students in professional colleges, which can undermine some of the very Title VI or international mandates of these programs. But placing area studies in international studies can reinforce their separation from domestic ethnic studies. At several universities deliberate efforts are being made to link African studies to professional schools as can be seen at the University of Michigan.

These programs typically undertake a similar range of teaching, research, and outreach activities despite the obvious differences of magnitude and effectiveness, which are partly determined by history, resources, and geographical location. At the undergraduate level, the African American studies or Africana studies programs typically offer majors, while most Title VI programs offer minors, concentrations or certificate, except for Michigan State, Ohio, UNC, and Yale, which offer a major. The same is true at the graduate level. For the stand-alone African studies programs Indiana, Ohio, Illinois and Yale offer an MA in African studies as well as in the case of Indiana and Yale joint MA degrees usually with professional fields. At the PhD level most only offer concentrations, minors, and certificates are offered, although PhDs focusing on Africa are routinely earned in various departments. Harvard and Brown have Ph.D. tracks in African studies in their African American studies and Africana studies departments, respectively. 
In addition, African, African American, and Africana studies programs provide opportunities for scholars and students in each of these fields to engage each other through seminars, public lectures, colloquia, workshops, conferences, and publications. Outreach within and outside campus is also common; the latter include communities ranging from schools and colleges to business, the media, and government, and involve the organization of summer or specialized institutes, exhibitions, and film series. Study abroad programs are also popular; they include those organized by the centers themselves, their universities, or by various consortia or independent providers.

\section{The Implications of the Obama Moment}

Let me conclude with a few thoughts on how the Obama era might affect the development of Africana studies. The rise of a member of the new African diaspora to the presidency of the United States recasts relationships between the new and historic diasporas in the U.S. and recasts the connections between Africa and its diasporas. It has encouraged the new diaspora to become more engaged in American politics in general and reinforced African American interest in Africa as the immediate homeland of President Obama's father. In short, the Obama presidency has buttressed the need to study developments on both sides of the Atlantic, indeed across the world, to better understand the pluralized African populations in the U.S., across the diaspora, and in Africa itself.

I am only too aware that it is too soon to pass definitive judgments on this unfolding era. Indeed a lot of the prognostications that we hear, especially the loud and often mindless punditry on cable, are premature because the Obama era is just two years old. Like most historical eras, it arose out of complex and contradictory national and global histories, and its trajectory will be no less complex and contradictory, even messy and bewildering. However, there is little doubt that the triumphant memories of President Obama's election and inauguration, which electrified the American, global, and PanAfrican imaginations have almost faded under the harsh demands of governance, in the face of Washington's descent into furious incivility and political gridlock verging on ungovernability.

The euphoria that temporarily lifted the country from the abyss of collective despondency has dissipated as the Great Recession continues to devastate lives and livelihoods, mock the fantasies of indebted consumption of the American dream; as levels of unemployment and underemployment remain stubbornly high. Fanciful dreams for a postracial future withered against the dreadful realities of what appears as a racist backlash against the country's first African American president.

The increasingly embattled Obama Administration finds itself buffeted between the angry Tea Party rabble of the right and the impatient progressives of the left. In the meantime, many African American leaders and voters are questioning the president's commitment to a "black agenda" more openly. They are disenchanted because they have been battered disproportionately by the ravages of the recession. In the 20ro Midterm elections, the Democrats were abandoned by many independent and white voters who only two years before had given them an overwhelming majority and lost power in Con- 
gress, and in Washington D.C. the much trumpeted post-racial mayor, Adrian Fenty, was defeated by disenchanted Black voters.

Elsewhere in the world, the giddy promises of the Obama era have largely lost their glow as the reflexes of American imperial power have reasserted themselves amidst the recycled rhetoric of multilateralism. And in the Pan-African world, from the continent itself to Afro-Latin America to Afro-Europe and Afro-Asia, the great expectations for a new dispensation for African peoples remain suspended in fading hope and growing uncertainty. The romance with Obama, which began to lose its seductions in Cairo, frayed in Accra, and fizzled in Copenhagen.

These rising discontents say more about the desperate desires pinned on an Obama presidency than the actual performance of his administration, which has passed some historic legislation including major reforms in health care, banking and finance, education and research, and energy. In the lame duck congressional session of December 2010, the Administration scored remarkable legislative victories including extending tax cuts and unemployment benefits, repealing the ban on gays serving in the military, ratiffing the new START treaty with Russia, and passing the most important food safety bill in decades, all of which helped nudge the President's poll numbers upwards.

The widespread sense of unease, even despair especially in progressive circles, reflects the unfulfilled great expectations during the presidential election for a new era of meaningful change after the disastrous years of the Bush Administration and the destructive legacies of neo-liberal fundamentalism that imploded in the Great Recession. President Obama has never presented himself as a fiery radical, let alone can he be considered a socialist by anyone who knows socialism, committed to profound social transformation. In the spectrum of American politics, he is a liberal centrist. In Pan-African politics, he would be regarded as a progressive conservative.

It is remarkable how soon many people seem to want to forget President Obama's horrible inheritance. As noted in an essay written on the day of President Obama's inauguration in Zeleza's (2009: 215) book, Barack Obama and African Diasporas, "the extraordinary euphoria that has gripped this nation and parts of the world is obviously unsustainable, and it will inevitably evaporate in the predictable whirlwind of stumbles, setbacks, even scandals, not to mention the structural obstacles, the systemic imperatives of this mighty but beleaguered capitalist country and imperial power that will constrain bold changes, truly progressive transformation. The challenges are immense indeed..."

To go back to the question of the potential impact of the Obama era on Africana studies, it is important to reprise the electric appeal of Obama the candidate to the PanAfrican world, which was rooted in his multiple biographies. Obama was incubated, physically and politically, in the whirlwind of African decolonization and the American civil rights movement. His varied racial, religious, cultural, spatial, and social affiliations make him the quintessential subject and sign, signifier and signified of a 2 Ist century Pan-African identity. He is a member of the new African diaspora in his migrant and transnational background. He benefitted immensely from the struggles of the historic diaspora, to which he is deeply connected through family, political apprenticeship, and electoral fortunes. 
President Obama's rise to the highest political office in the world's lone, albeit declining superpower, cannot but intensify dialogues and recast the dissensions between Africa and its Diasporas, African Studies and African American Studies. His personal narrative reinforces the rising appeal of the Diaspora paradigm in African studies. The evident backlash against his presidency, often couched in barely disguised racist rhetoric, puts to rest the canard that his election marked the birth of a postracial America. This might enrich, if not reinscribe, critical race theories and analyses developed in Africana studies and other ethnic and disapora studies fields.

Clearly, one electoral victory cannot overturn four centuries of African American racial oppression and exploitation. Nor can relations between the U.S. and Africa be expected to change fundamentally because the son of Kenyan foreign student is in the White House. The dreams of the Civil Rights movement and the African nationalists, of Dubois and Nkrumah, remain deferred. But the power of the Obama moment in the PanAfrican imagination lies in the historical legacies, the struggles that brought it about, and the possibilities it beckons.

With the Obama presidency, the political enfranchisement of the diaspora enters a new period, reminiscent of Africa's decolonization during which the nationalists gained political power. But just as independence in Africa did not bring to an end struggles for development, democracy and self-determination, an African American's electability to the U.S. presidency cannot bring to an end struggles for democratic citizenship and socioeconomic empowerment in the diaspora. Such struggles simply enter a new phase.

\section{Conclusion}

The fates of African peoples remain intertwined, indeed are even more so today than at the turn of the twentieth century when the Pan-Africanist movement was born. And since African peoples are an essential part of our rapidly globalizing world, their study is a vital component of globalization, indispensable indeed to a deeper understanding of our common humanity. This is why, it can be argued, Africana studies, as a project informed by radical politics and critical theory, promises so much for advancing scholarship and for cultivating global citizenship. But if it is to discharge its critical emancipatory mission for both society and scholarship, for intellectual enlightenment, social engagement and political empowerment, it must become truly interdisciplinary and international, and shed its defensive supplication to the Eurocentrisism of the disciplines and the export of U.S. academic ethnocentrism.

Those who claim theories, stylized facts and narratives constructed out of limited experiences of a small portion of humanity are the epitome of intellectual rigor and excellence are quite amusing in their misguided civilizational conceit. Africana scholars must continue critiquing such conceits and deconstructing the deeply entrenched edifice of Eurocentrisism embedded in the disciplines created in the igth and early 20 th centuries when the Euroamerican world was hegemonic politically, economically, and intellectually. At the same time they need to create more empowering knowledges from multicultural, multi-methodological, multidisciplinary, and multi-theoretical perspectives that are 
more befitting the pluralized worlds of the 2 rst century. These must also be knowledges that give true content and meaning to transformative engaged scholarship.

These struggles are essential for raising the intellectual standing of Africana scholars and scholarship, which continues to be low in an era when the epistemic and ethical values they profess, namely, interdisciplinarity, internationalization, and interculturalism are professed by many in the academy and are sorely needed in public life. They are also indispensable for their institutional viability and sustainability in an era of diminishing resources in which collaboration among academic programs and even consolidation is becoming a financial imperative.

In short, the future for African, African American, Diaspora and Africana studies in the United States and elsewhere can only be assured through critical understanding of the complex and shifting terrain of higher education, the changing intellectual, institutional, and ideological dynamics of knowledge production in different spatial and institutional locations, and the ability to undertake strategic and creative interventions, engagements, and transformations.

\section{References}

Abott, A. (1995). The System of Professions. Chicago: University of Chicago Press.

Adeleke, T. (2009). The Case Against Afrocentricism. Jackson, Miss: University of Mississippi Press.

Aldridge, D. P. and Young, C. (2000). Out of the Revolution: The Development of Africana Studies. Boulder, CO: Lexington Books.

Arthur, J. A. (2000). Invisible Sojourners: African Immigrant Diaspora in the United States. Westport, CT: Praeger.

- (2009). African Women Immigrants in the United States: Crossing Transnational Borders. New York: Palgrave Macmillan.

- African Diaspora Identities: Negotiating Culture in Transnational Migration. Lanham, MD: Lexington Books.

Asante, M. K. (2006). A Discourse on Black Studies: Liberating the Study of African People in the Western Academy. In: Journal of Black Studies, $36(5): 646-662$.

- (1988). Afrocentricity. Trenton, N. J.: Africa World Press.

Azevedo, M., (ed.), (1998). African Studies: A Survey of Africa and the African Diaspora. 2nd ed. Durham, NC: Carolina Academic Press.

Bankole, K. O. (2006). A Preliminary Report and Commentary on The Structure of Graduate Afrocentric Research and Implications for the Advancement of the Discipline of Africalogy, 1980-2004. In: Journal of Black Studies, 36 (5): 663-697.

Banks, W. M. (1996). Black Intellectuals: Race and Responsibility in American Life. New York: W. W. Norton.

Barrett, M. and Carey, P., (eds.), (2003). The Diaspora: Introduction to Africana Studies. Dubuque, Iowa: Kendall/Hunt Publishing.

Bates, R.H., Mudimbe, V.Y., O'Barr, J. (eds.), (1993). Africa and the Disciplines. The Contributions of Africa to the Social Sciences and Humanities. Chicago and London: University of Chicago Press.

Bennett, P. R. and Lutz, A. (2009). How African Americans Is the Net Black Advantage? Differences in College Attendance Among Immigrant Blacks, Native Blacks, and Whites. In: Sociology of Education, 82: 70-100.

Bobo, J., Hudley, C., and Michel, C., (eds.), (2004). The Black Studies Reader. New York: Routledge.

Brown, C. (2007 ). Dude, Where's My Black Studies Department: The Disappearance of Black Americans from Our Universities. Berkeley, CA: North Atlantic Books. 
Challenor, H. S. (2002). African Studies at Historically Black Colleges and Universities. In: African Issues, 30 (2): 24-29.

Christian, M. (2006). The State of Black Studies in the Academy. In: Journal of Black Studies, 36 (5): 643-645.

Conyers, J. L., (ed.), (2005). Afrocentric Traditions. New Brunswick, N.J.: Transaction Publishers.

Davies, C. B. (1999). Beyond Unicentricity: Transcultural Black Presences. In: Research in African Literatures, 30 (2): 96-109.

Drake, St. Clair and Horace R. Cayton. (1993 [1945]. Black Metropolis: A Study of Negro Life in a Northern City. Chicago: University Of Chicago Press.

Dubois, W.E.B. ([1899] 1995). The Philadelphia Negro: A Social Study. Philadelphia: University of Pennsylvania.

- (1896). The Suppression of the African Slave Trade to the United States of America 1638-1870. New York: Longmans, Green, and Co.

- ([1935] 1998). Black Reconstruction in America, 1860-188o. New York: Free Press.

Eissa, S. O. (2005). Diversity and Transformation: African Americans and African Immigration to the United States. Immigration Policy Brief available at http://www.ailf.org/diversityandtransformationprint.asp.

Escobar, Arturo. 1994. Encountering Development: The Making and Unmaking of the Third World. Princeton, NJ: Princeton University Press.

Frazier, F. (1939). The Negro Family in the United States. Chicago: University of Chicago Press.

- (1957). Black Bourgeoisie. Glencoe, IL: Free Press.

Fyfe, C. (1976). African Studies since 1945. London: Longman.

Gomez, M. A. (2004). Of Du Bois and Diaspora: The Challenge of African American Studies. In: Journal of Black Studies, 35 (2): 175-194.

Gordon, L. R. and Gordon, J. A., (eds.), (2006). A Companion to African American Studies. Malden, MA: Blackwell.

Griffin, F. J. (2004). Thirty Years of Black American Literature and Literary Studies: A Review. In: Journal of Black Studies, 35 (2): $165-174$.

Guyer, J. (1996). African Studies in the United States: A Perspective. Atlanta, GA: African Studies Association.

Guy-Sheftall, Beverly. (1998). Shifting Contexts: Lessons from Integrating Black, Gender, and African Diaspora Studies. In: Women's Studies Quarterly, 26 (3/4): 17-24.

Hanchard, M. G. (2004). Black Transnationalism, Africana Studies, and the $215 t$ Century. In: Journal of Black Studies, 35 (2): 139-153.

Harris, R. L. (1982). Segregation and Scholarship: The American Council of Learned Societies' Committee on Negro Studies, 1941-1950. In: Journal of Black Studies, 12 (3): 315-331.

Hawkins, J. et al., (eds.), (1998). International Education in the New Global Era. Los Angeles: International Studies and Overseas Programs, University of California.

Howe, S. (1998). Afrocentricism: Mythic Pasts and Imagined Homes. New York: Verso.

Jacoby, Russell. (2000). The Last Intellectuals: American Culture in the Age of Academe. New York: Basic Books.

Johnson, J. B. (2005). Shades of gray in black enrollment: Immigrants' rising numbers a concern to some activists. In: The San Francisco Gazette, February 22.

Journal of Black Studies. (2004). Special Issue on race in the Academy: Moving Beyond Diversity and Toward the Incorporation of Faculty of Color in Predominantly White Colleges and Universities, Vol. 34, No. I.

Mann, A. (2010). The Struggle for Black Studies at HBCUs. The Root at: http://www.theroot.com/views/hbcu-black-studies.

Marable, M. (1995). Black Studies, Multiculturalism, and the Future of American Education. In: Items, 49 (2/3): 49-57.

Martin, W. G. and M. O. West, (eds.), (1999). Out of One, Many Africas: Reconstructing the Study and Meaning of Africa. Urbana and Chicago: University of Illinois Press. 
Mayhew, M. J. and Grunwald, H. E. (2006). Factors Contributing to Faculty Incorporation of Diversity-Related Course Content. In: The Journal of Higher Education, 77 (1): 148-168.

Mazama, A., (ed.) (2003). The Afrocentric Paradigm. Trenton, N. J.: Africa World Press.

Mazrui, A. A. (1996). The African Diaspora and Globalization. Paper presented at the conference on the African Diaspora, SUNY Binghamton, April 13.

Mbabuike, M. C. (2000). Wonders Shall Never Cease: Decoding Henry Louis Gates's Ambiguous Adventure. In: Journal of Black Studies, 3I (2): 232-246.

Miyoshi, M. and Harootunian, H. D. (2002) Learning Places: The Afterlives of Area Studies. Durham, NC: Duke University Press.

O'Connell, M. E. and Norwood, J. L., (eds.), (2007). International Education and Foreign Languages: Keys to Securing America's Future. Washington, D.C.: National Academies Press.

O'Meara, P. et al., (eds.), (200I). Changing Perspectives on International Education. Bloomington: Indiana University Press.

Okpewho, I. and Nzegwu, N., (eds.), (2009). The New African Diaspora. Bloomington. In: Indiana University Press.

Olaniyan, T. and Sweet, J. H. (2010). The African Diaspora and the Disciplines. Bloomington: Indian University POress.

Rabaka, R. (2006). The Souls of Black Radical Folk: W.E.B. Du Bois, Critical Social Theory, and the State of Africana Studies. In: Journal of Black Studies, $36(5): 732-763$.

Rimer, S. and Arenson, K. W. (2004). Top Colleges Take More Blacks, But Which Ones? In New York Times, June 24.

Robinson, P. T. (2007). Area Studies in Search of Africa: The Case of the United States. In Paul Tiyambe Zeleza, (ed.), The Study of Africa, Volume 2: Global and Transnational Engagements. Dakar: Codesria Book Series.

Rojas, F. (2007). From Black Power to Black Studies: How A Radical Social Movement Became and Academic Discipline. Baltimore: The Johns Hopkins University Press.

Rooks, N. (2006). White Money/Black Power: The Surprising History of African American Studies and the Crisis of Race and Higher Education. Boston: Beacon Press.

Small, M. (1999). Departmental conditions and the emergence of new disciplines: Two cases in the legitimation of African-American Studies. In: Theory and Society, 28: 659-707.

Stanley, C. A. (2006). Coloring the Academic Landscape: Faculty of Color Breaking the Silence in Predominantly White Colleges and Universities. In: American Educational Research Journal, 43 (4): 701-736.

When Counter Narratives Meet Master narratives in the Journal Editorial-Review Process. In: Educational Researcher, 36 (1): 14-24.

Szanton, D., (ed.), (2004). The Politics of Knowledge: Area Studies and the Disciplines. Berkeley: University of California Press, $1-33$.

Temple, C. N. (2006). Rescuing the Literary in Black Studies. In Journal of Black Studies, 36 (5): 764-785.

The Journal of Blacks in Higher Education (2004). Is the magic Gone from Black Studies at Harvard? 9I-94.

Thomas, G. D. and Hollenshead, C. (2001). Resisting from the Margins: The Coping Strategies of Black Women of Color Faculty Members at a Research University. In The Journal of Negro Education, 70 (3): 166-175.

Tillman, L. C. (2001). Menoting African American faculty in Predominantly White Institutions. In Research in Higher Education, 42 (3): 295-325.

Wiley, D. and Glew R. S. (2010). International and Language Education for a Global Future: Fifty Years of U.S. Title VI and Fulbright-Hays Programs. East Lansing: Michigan State University Press.

Zeleza, P. T. (2003). The Pasts and Futures of African Studies. In Paul Tiyambe Zeleza, Rethinking Africa's Globalization, Volume I: The Intellectual Challenges, Trenton, NJ: Africa World Press, 179-227.

- (2004). The African Academic Diaspora in the United States and Africa: The Challenges of Productive Engagement. Comparative Studies of South Asia, Africa, and the Middle East 24, I: 265-278. 
- (2005). Rewriting the African Diaspora: Beyond the Black Atlantic. In African Affairs, 104, 1: 35-68.

- (2008). Contemporary African Global Migrations: Patterns, Perils, and Possibilities. In Journal of Global Initiatives, 3, $1: 33-56$.

- (2009). African Studies and Universities since Independence. In Transition, 101: 110-1 35

- (2009). Barack Obama and African Diasporas: Dialogues and Dissensions. Oxford, UK and Athens, Ohio: Ayebia Clarke Publishing and Ohio University Press.

- (2010). African Diasporas: Towards a Global History. In African Studies Review, 53, I: I-I9.

Zeleza, P. T. and Olukoshi. A. (2004a). African Universities in the 21st Century, Volume1: Liberalization and Internationalization. Dakar, Pretoria: Codesria Book Series, University of South Africa Press, xiii+317pp. (2004b). African Universities in the 21st Century, Volume 2: Knowledge and Society. Dakar, Pretoria: Codesria Book Series, University of South Africa Press, xii+356pp. (Co-edited with Adebayo Olukoshi).

Zeleza, P. T., (ed.), (2007). The Study of Africa, Volume 2: Global and Transnational Engagements. Dakar: Codesria Book Series.

\section{Note}

An earlier version of this paper was presented at the conference on "[Un]Disciplined Encounters: Science as Terrain of Postcolonial Interaction between Africa and Europe," Ghent University, University Foundation, Brussels, Belgium, November 5-6, 2010. 